\title{
Commentary Caudwell Xtreme Everest: a field study of human adaptation to hypoxia
}

\author{
Mike Grocott ${ }^{1}$, Alan Richardson ${ }^{2}$, Hugh Montgomery ${ }^{1}$ and Monty Mythen ${ }^{1}$
}

${ }^{1}$ Centre for Altitude, Space and Extreme Environment Medicine (CASE Medicine), UCL Institute of Human Health and Performance, Ground Floor, Charterhouse Building, UCL Archway Campus, Highgate Hill, London, N19 5LW, UK

${ }^{2}$ Chelsea School, University of Brighton, Hillbrow, Denton Road, Eastbourne BN20 7SR, UK

Corresponding author: Monty Mythen, montymythen@btinternet.com

Published: 1 August 2007

This article is online at http://ccforum.com/content/11/4/151

(c) 2007 BioMed Central Ltd
Critical Care 2007, 11:151 (doi:10.1186/cc5921)

not present. Hypoxia may occur as either a cause of or as a consequence of a variety of critical illnesses. Hypoxia mediated cell death may lead to the generation of an inflammatory response. Systemic inflammation is associated with the development of cellular hypoxia caused by decreased tissue oxygen delivery associated with microcirculatory dysfunction. Cellular hypoxia may also be caused by alterations in cellular energy pathways and mitochondrial function, resulting in decreased ability to utilize available oxygen $[2,3]$. Although our dominant treatment paradigm revolves around maintenance of oxygen delivery to the cells, there are few data to guide the optimal level of inspired oxygen. Moreover, in some circumstances increasing oxygen delivery confers no benefit or may even cause harm; for example, elevating haemoglobin levels or 'optimization' of oxygen delivery to specific goals in established critical illness [4-6]. Might it be that variations in the cellular efficiency of oxygen metabolism account for some of the observed differences in outcome following critical illness?

The high altitude physiology literature gives us an elegant general description of adaptation to environmental hypoxia built around the idea that maintenance of oxygen delivery to the tissues will allow normal cellular function [7]. However, to date none of these adaptations explain observed (and dramatic) differences in performance between individuals at altitude. Again, the possibility that observed differences are not accounted for by variations in elements of the dominant paradigm raises the possibility that an unmeasured factor or factors may be important. The core hypothesis that CXE is addressing is that variations in metabolic efficiency (relationship between oxygen uptake and work rate) may explain, at least in part, observed differences in individuals' abilities to adapt to hypoxia. If this is true, then it may be

$\mathrm{CXE}=$ Caudwell Xtreme Everest. 
possible - by examining the genotype and phenotype of the 'rapid adaptors' - to identify mechanisms and thereby develop treatments to benefit the 'slow adaptors' [8-10].

The studies conducted in CXE involve a variety of techniques, including cardiopulmonary exercise testing on cycle ergometers using breath-by-breath expired gas analysis, neuropsychological assessment, near infrared spectroscopy of brain and exercising muscle, blood markers (inflammatory and neuroendocrine) and daily recording of simple physiological variables [1]. These measurements and many more were taken in London before departure, in four laboratories in Nepal on the ascent to Everest Base Camp, and in two laboratories high on Mount Everest. The next few years will see whether this new approach to investigating the pathogenesis of critical illness bears fruit.

\section{Competing interests}

The authors are all investigators in the CXE research group.

\section{Authors' contributions}

$A R, M M, H M$ and $M G$ were all involved in either (or all) of original drafting, review and redrafting of the mansucript.

\section{Acknowledgement}

The research was funded from a variety of sources, none of which are public. The entrepreneur John Caudwell, whose name the expedition carries, donated $£ 500,000$ specifically to support the research. BOC Medical, now part of the Linde Group, generously supported the research early on and continues to do so. Ely-Lilly Critical Care, The London Clinic (a private hospital), Smiths Medical, Deltex Medical and Rolex have also donated money to support the research and logistics. All monies were given as unrestricted grants. Specific research grants were awarded by the Association of Anaesthetists of Great Britain and Ireland, and the UK Intensive Care Foundation. The CXE trekkers themselves also kindly donated to support the research [1].

\section{References}

1. Caudwell Xtreme Everest [www.xtreme-everest.co.uk]

2. Fink MP: Bench-to-bedside review: cytopathic hypoxia. Crit Care 2002, 6:491-499.

3. Protti A, Singer M: Bench-to-bedside review: potential strategies to protect or reverse mitochondrial dysfunction in sepsis-induced organ failure. Crit Care 2006, 10:228.

4. Hayes MA, Yau EH, Timmins AC, Hinds CJ, Watson D: Response of critically ill patients to treatment aimed at achieving supranormal oxygen delivery and consumption. Relationship to outcome. Chest 1993, 103:886-895.

5. Pearse R, Dawson D, Fawcett J, Rhodes A, Grounds RM, Bennett ED: Early goal-directed therapy after major surgery reduces complications and duration of hospital stay. A randomised, controlled trial. Crit Care 2005, 9:R687-R693.

6. Rivers E, Nguyen B, Havstad S, Ressler J, Muzzin A, Knoblich B, Peterson E, Tomlanovich M; Early Goal-Directed Therapy Collaborative Group: Early goal-directed therapy in the treatment of severe sepsis and septic shock. N Engl J Med 2001, 345:1368-1377.

7. Grocott M, Montgomery H, Vercueil A: High-altitude physiology and pathophysiology: implications and relevance for intensive care medicine. Crit Care 2007, 11:203.

8. Marshall RP, Webb S, Bellingan GJ, Montgomery HE, Chaudhari B, McAnulty RJ, Humphries SE, Hill MR, Laurent GJ: Angiotensin converting enzyme insertion/deletion polymorphism is associated with susceptibility and outcome in acute respiratory distress syndrome. Am J Respir Crit Care Med 2002, 166:646-650.

9. Montgomery $\mathrm{H}$, Clarkson $\mathrm{P}$, Barnard M, Bell J, Brynes A, Dollery C, Hajnal J, Hemingway $H$, Mercer $D$, Jarman $P$, et al:: Angiotensin-converting-enzyme gene insertion/deletion poly- morphism and response to physical training. Lancet 1999, 353:541-545.

10. Tsianos G, Eleftheriou KI, Hawe E, Woolrich L, Watt M, Watt I, Peacock A, Montgomery $\mathrm{H}$, Grant S: Performance at altitude and angiotensin I-converting enzyme genotype. Eur J Appl Physiol 2005, 93:630-633. 